\title{
ANALISIS PENGARUH SOSIALISASI PERPAJAKAN, KUALITAS PELAYANAN FISKUS DAN SANKSI PERPAJAKAN TERHADAP KEPATUHAN WAJIB PAJAK ORANG PRIBADI DI KANTOR PELAYANAN PAJAK PRATAMA MANADO
}

\author{
Ayu Try Setiyoningrum, Jantje Tinangon, dan Heince R. N. Wokas \\ Email : ayutry1906@gmail.com
}

\begin{abstract}
This study aims to analyze the influence of tax audit against the compliance level of corporate taxpayer to fulfilling the taxation obligations in KPP Pratama Manado(Manado Small Tax Office). The analysis method used in this research is descriptive to describe the influence of tax audit against the compliance level of corporate taxpayer to fulfilling the taxation obligations in KPP Pratama Manado. Based on the partial research results note that taxation has an influence on the socialization of individual taxpayer compliance, quality of service tax authorities have no effect on an individual taxpayer compliance and tax penalties have no effect on an individual taxpayer compliance. While based on research results simultaneously, socialization taxation, quality of service tax authorities and tax penalties as independent variables jointly affect the individual taxpayer compliance._Suggestions for KPP Pratama Manado is tax officials should be more active in conducting counseling and socialization taxes, behave professionally to serve taxpayers and improve tax penalties for taxpayers who do not comply.
\end{abstract}

Keywords: Socialization Taxation, Quality Service of Tax Authorities, Tax Penalties, Taxpayer Compliance

\section{Latar Belakang Penelitian}

\section{PENDAHULUAN}

Pajak merupakan kontribusi wajib kepada negara yang terutang oleh orang pribadi atau badan yang bersifat memaksa berdasarkan Undang-Undang, dengan tidak mendapatkan imbalan secara langsung dan digunakan untuk keperluan negara bagi sebesar-besarnya kemakmuran rakyat (UU No. 28 Tahun 2007).

Pajak merupakan sumber penerimaan utama negara yang digunakan untuk membiayai pengeluaran pemerintah dan pembangunan. Hal ini tertuang dalam Anggaran Penerimaan dan Belanja Negara (APBN) dimana penerimaan pajak merupakan penerimaan dalam negeri yang terbesar. Semakin besarnya pengeluaran pemerintah dalam rangka pembiayaan negara menuntut peningkatan penerimaan negara yang salah satunya berasal dari penerimaan pajak. Tugas mulia administrasi perpajakan, terutama administrasi pajak pusat, diemban oleh Direktorat Jenderal Pajak sebagai salah satu instansi pemerintah yang secara struktural berada di bawah Kementerian Keuangan (Salahuddin, 2005).

Peran serta Wajib Pajak dalam sistem pemungutan pajak sangat menentukan tercapainya rencana penerimaan pajak. Penerimaan pajak yang optimal dapat dilihat dari berimbangnya tingkat penerimaan pajak aktual dengan penerimaan pajak potensial atau tidak terjadi tax gap sebab "besarnya tax gap mencerminkan kurangnya kepatuhan membayar pajak (tax compliance), oleh karena itu kepatuhan Wajib Pajak merupakan faktor utama yang mempengaruhi realisasi penerimaan pajak. Kepatuhan yang dimaksud merupakan istilah tingkat sampai dimana Wajib Pajak membayar dan melaporkan pajak terutangnya tepat waktu, maka Wajib Pajak dianggap 
patuh (Saragih, 2013). Definisi dari kepatuhan itu sendiri merupakan suatu ketaatan untuk melakukan ketentuan-ketentuan atau aturan-aturan perpajakan yang diwajibkan atau diharuskan untuk dilaksanakan (Jatmiko, 2006).

Kantor Pelayanan Pajak (KPP) Pratama Manado merupakan salah satu unit vertikal DJP di Sulawesi Utara yang selama ini terus berupaya meningkatkan kepatuhan Wajib Pajak di wilayah kerjanya melalui kegiatan sosialisasi perpajakan, kualitas pelayanan fiskus dan sanksi perpajakan guna meningkatkan penerimaan pajak.

\section{Tujuan Penelitian}

Tujuan dari penelitian ini yaitu:

1. Untuk mengetahui pengaruh sosialisasi perpajakan, kualitas pelayanan fiskus, dan sanksi perpajakan secara simultan terhadap kepatuhan Wajib Pajak orang pribadi pada KPP Pratama Manado.

2. Untuk mengetahui pengaruh sosialisasi perpajakan secara parsial terhadap kepatuhan Wajib Pajak orang pribadi pada KPP Pratama Manado.

3. Untuk mengetahui pengaruh kualitas pelayanan fiskus secara parsial terhadap kepatuhan Wajib Pajak orang pribadi pada KPP Pratama Manado.

4. Untuk mengetahui pengaruh sanksi perpajakan secara parsial terhadap kepatuhan Wajib Pajak orang pribadi pada KPP Pratama Manado.

\section{Konsep Pajak}

\section{TINJAUAN PUSTAKA}

Saragih (2013), Wajib Pajak adalah orang pribadi atau badan yang menurut ketentuan peraturan perundang-undangan perpajakan ditentukan untuk melakukan kewajiban perpajakan termasuk pemungut atau pemotong pajak tertentu. UU No. 28 Tahun 2007, Wajib Pajak adalah orang pribadi atau badan, meliputi pembayar pajak dan pemungut pajak yang mempunyai hak dan kewajiban perpajakan sesuai dengan ketentuan peraturan perundang-undangan perpajakan.

\section{Sosialisasi Perpajakan}

Sosialisasi perpajakan adalah upaya yang dilakukan oleh Ditjen Pajak untuk memberikan sebuah pengetahuan kepada masyarakat dan khususnya Wajib Pajak agar mengetahui tentang segala hal mengenai perpajakan baik peraturan maupun tata cara perpajakan melalui metodemetode yang tepat (Saragih, 2013). Susanto (2012) menyatakan bahwa upaya dalam meningkatkan kesadaran dan kepatuhan Wajib Pajak dilakukan dengan sosialisasi perpajakan dengan beragam bentuk atau cara sosialisasi. Namun, kegiatan sosialisasi harus dilakukan secara efektif dan dilakukan dengan media-media yang lain yang lebih diketahui masyarakat (Herryanto, 2009).

\section{Kualitas Pelayanan Fiskus}

Pelayanan adalah cara melayani (membantu mengurus atau menyiapkan segala keperluan yang dibutuhkan seseorang). Sementara itu fiskus adalah petugas pajak. Pelayanan fiskus dapat diartikan sebagai cara petugas pajak dalam membantu mengurus atau menyiapkan segala keperluan yang dibutuhkan Wajib Pajak (Fikriningrum, 2012). Kualitas pelayanan fiskus sangat berpengaruh terhadap Wajib Pajak dalam membayar pajaknya, Oleh karena itu, fiskus dituntut untuk memberikan pelayanan yang ramah, adil, dan tegas setiap saat kepada Wajib Pajak serta 
dapat memupuk kesadaran masyarakat tentang tanggung jawab membayar pajak. Pemberian jasa oleh aparat pajak kepada Wajib Pajak besar manfaatnya sehingga dapat menimbulkan kesadaran Wajib Pajak dalam memenuhi kewajiban perpajakannya.

\section{Sanksi Perpajakan}

Sanksi adalah suatu tindakan berupa hukuman yang diberikan kepada orang yang melanggar peraturan. Peraturan atau Undang-undang merupakan rambu-rambu bagi seseorang untuk melakukan sesuatu mengenai apa yang harus dilakukan dan apa yang seharusnya tidak dilakukan. Sanksi diperlukan agar peraturan atau Undang-undang tidak dilanggar. Sanksi pajak merupakan jaminan bahwa ketentuan peraturan perundang-undangan perpajakan (norma perpajakan) akan dituruti/ditaati/dipatuhi, dengan kata lain sanksi perpajakan merupakan alat pencegah agar Wajib Pajak tidak melanggar norma perpajakan (Arum, 2012).

\section{Kepatuhan Wajib Pajak}

Dalam pajak, aturan yang berlaku adalah Undang-Undang Perpajakan. Kepatuhan pajak merupakan kepatuhan seseorang, dalam hal ini adalah Wajib Pajak, terhadap peraturan atau Undang-Undang Perpajakan. Kepatuhan Wajib Pajak merupakan pemenuhan kewajiban perpajakan yang dilakukan oleh pembayar pajak dalam rangka memberikan kontribusi bagi pembangunan negara yang diharapkan didalam pemenuhannya dilakukan secara sukarela. Kepatuhan Wajib Pajak menjadi aspek penting mengingat sistem perpajakan Indonesia menganut sistem Self Assessment di mana dalam prosesnya mutlak memberikan kepercayaan kepada Wajib Pajak untuk menghitung, membayar dan melapor kewajibannya (Tryana, 2013).

\section{Permasalahan Dalam Kepatuhan Wajib Pajak}

Penyebab Wajib Pajak tidak patuh bervariasi, sebab utama adalah penghasilan yang di peroleh Wajib Pajak yang utama ditujukan untuk memenuhi kebutuhan hidupnya. Timbulnya konflik antara, kepentingan diri sendiri dan kepentingan Negara. Sebab lain adalah Wajib Pajak kurang sadar tentang kewajiban bernegara, tidak patuh pada aturan, kurang menghargai hukum, tingginya tarif pajak, dan kondisi lingkungan sekitar (Jatmiko,dalam Saragih, 2013). Umumnya masyarakat disetiap Negara memiliki kecenderungan untuk meloloskan diri dari pembayaran pajak. Permasalahan tersebut timbul dari pemikiran bahwa pembayaran pajak adalah pengorbanan yang dilakukan warga Negara dengan menyerahkan sebagian hartanya kepada Negara dengan sukarela. Usaha yang dilakukan Wajib Pajak untuk meloloskan diri dari pajak merupakan usaha yang disebut perlawanan terhadap pajak. Berbagai bentuk perlawanan sebagai bentuk reaksi ketidakcocokan ataupun ketidakpuasan terhadap diberlakukannya pajak sering kali diwujudkan dalam bentuk perlawanan pasif dan perlawanan aktif.

\section{Hipotesis Penelitian}

1. Sosialisasi perpajakan secara parsial berpengaruh signifikan terhadap kepatuhan Wajib Pajak orang pribadi.

2. Kualitas pelayanan fiskus secara parsial berpengaruh signifikan terhadap kepatuhan Wajib Pajak orang pribadi.

3. Sanksi perpajakan secara parsial berpengaruh signifikan terhadap kepatuhan Wajib Pajak orang pribadi. 
Jenis penelitian

\section{METODE PENELITIAN}

Jenis penelitian ini merupakan penelitian kausal (causal) dengan teknik survey (Saragih, 2013) menyebutkan desain kausal berguna untuk menganalisis bagaimana suatu variabel mempengaruhi variabel lain, dan juga berguna pada penelitian yang bersifat eksperimen, dimana variabel independennya diperlakukan secara terkendali oleh peneliti untuk melihat dampaknya pada variabel dependennya secara langsung.

\section{Tempat dan Waktu Penelitian}

Lokasi penelitian yaitu pada Kantor Pelayanan Pajak (KPP) Pratama Manado, Jalan Gunung Klabat Manado. Penelitian ini mulai dari bulan Mei 2014 sampai bulan September 2014.

\section{Populasi dan Sampel}

Populasi dalam penelitian ini adalah Wajib Pajak orang pribadi efektif yang terdaftar pada Kantor Pelayanan Pajak (KPP) Pratama Manado. Jumlah sampel yang di ambil dalam penelitian ini adalah sebanyak 100 Wajib Pajak orang pribadi. Pengambilan sampel dilakukan dengan Metode Nonprobability Sampling dengan penarikan Insidential Sampling (Sugiyono, 2013:120).

\section{Metode Pengumpulan Data}

Metode pengumpulan data dalam penelitian ini adalah wawancara yaitu dengan teknik kuesioner dimana pengumpulan data yang dilakukan dengan cara memberi seperangkat pertanyaan atau pernyataan tertulis kepada responden untuk di jawab.

\section{Metode Analisis Data}

Analisis ini dilakukan dengan menggunakan teknik analisis regresi berganda dengan tingkat signifikansi 0,05. Analisis ini digunakan untuk mengetahui atau memperoleh gambaran mengenai pengaruh variabel bebas terhadap variabel terikat. Model regresi linear berganda ini dirumuskan sebagai berikut :

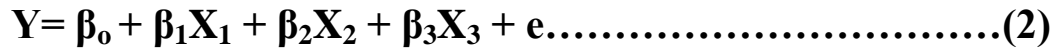

$\mathrm{Y} \quad=$ Kepatuhan pelaporan Wajib Pajak orang pribadi

$\mathrm{X}_{1} \quad=$ Sosialisasi Perpajakan

$\mathrm{X}_{2} \quad=$ Kualitas Pelayanan Fiskus

$\mathrm{X}_{3}=$ Sanksi Perpajakan

\section{Uji Kualitas Data Uji Validitas}

Uji Validitas adalah suatu ukuran yang menunjukan tingkat ketepatan suatu instrument. Untuk menguji apakah angket yang digunakan memenuhi syarat validitas, pada dasarnya digunakan korelasi pearson. Cara analisisnya dengan cara menghitung koefisien korelasi antara masing-masing nilai pada nomor pertanyaan dengan nilai total dari nomor pertanyaan tersebut. Selanjutnya koefisien korelasi yang diperoleh masih harus diuji signifikansinya bisa menggunakan uji t atau membandingkannya dengar $r$ tabel dengan asumsi:

1. Bila $t$ hitung $>$ dari $t$ tabel atau $r$ hitung $>$ dari $r$ tabel, maka nomor pertanyaan tersebut valid 
2. Bila $\mathrm{t}$ hitung $<$ dari $\mathrm{t}$ tabel atau $\mathrm{r}$ hitung $<$ dari $\mathrm{r}$ tabel, maka nomor pertanyaan tersebut tidak valid

\section{Uji Reliabilitas}

Pengujian reliabilitas instrument dapat dilakukan dengan korelasi Spearman Brown, Yaitu : dimana ri adalah reliabilitas internal seluruh instrument dan rb adalah korelasi product Moment. Perhitungan Reliabilitas menggunakan Cronbach Alpha. Jika nilai :

1. Cronbach Alpha atau a $>0.70$ maka instrument reliable,

2. Jika Cronbach Alpha a $<0.70$ maka instrument tidak reliable.

\section{Uji Asumsi Klasik \\ Uji Normalitas}

Uji normalitas data dilakukan untuk melihat bahwa suatu data terdistribusi secara normal atau tidak. Uji normalitas data dilakukan dengan menggunakan histogram standardized residual. Asumsi normalitas data dipenuhi jika nilai statistik Kolmogrof - Smirnov diatas tingkat signifikansi tertentu :

1. Apabila tingkat signifikansi $<0.05$ maka distribusi data tidak normal,

2. Apabila nilai signifikan $>0,05$ berarti distribusi normal.

\section{Uji Heteroskedastisitas}

Heteroskedastisitas terjadi apabila tidak adanya kesamaan deviasi standar nilai variabel dependen pada setiap variabel independen. Bila terjadi gejala heteroskedastisitas akan menimbulkan akibat varians koefisien regresi menjadi minimum dan confidence interval melebar sehingga hasil uji signifikan statistik tidak valid lagi.

\section{Uji Multikolinearitas}

Uji multikolinearitas ini dimaksudkan untuk mengetahui apakah terdapat inter korelasi yang sempurna diantara beberapa variabel bebas yang digunakan dalam model. Uji asumsi klasik seperti multikolinearitas dapat dilaksanakan dengan jalan meregresikan model analisis dan melakukan uji korelasi antara independent variabel dengan menggunakan variance inflating factor (vif). Batas dari vif adalah 10 dan nilai tolerance value adalah 0,1. Dengan uji asumsi :

1. Jika nilai vif $>$ dari 10 dan nilai tolerance value $<0,1$ maka terjadi multikolinearitas,

2. Jika nilai vif $<$ dari 10 dan nilai tolerance value $>0,1$ maka tidak terjadi multikolinearitas.

\section{Pengujian Hipotesis}

Uji Parsial (Uji t)

Uji $\mathrm{t}\left(\mathrm{t}_{\mathrm{test}}\right)$ atau uji parsial digunakan untuk menguji koefisien regresi secara parsial dari variabel bebas terhadap variabel terikat. Untuk menentukan $t_{\text {tabel }}$, taraf signifikan yang digunakan sebanyak 5\% dengan derajat kebebasan $(\mathrm{df})=(\mathrm{n}-\mathrm{k}-1)$, dimana $\mathrm{n}$ merupakan jumlah observasi dan k merupakan jumlah variabel bebas.

\section{Uji Simultan (Uji F)}

Uji f merupakan pengujian terhadap signifikansi model secara simultan atau bersamasama, yaitu melihat pengaruh dari seluruh variabel bebas terhadap variabel terikat. Untuk 
menentukan nilai $\mathrm{f}_{\text {hitung }}$ tingkat signifikan yang digunakan sebesar 5\% dengan derajat kebebasan $(\mathrm{df})=(\mathrm{k}-1)$ dan $(\mathrm{n}-\mathrm{k})$.

\section{HASIL PENELITIAN DAN PEMBAHASAN}

Statistik Deskriptif Variabel-variabel Penelitian

Tabel 1. Statistik Deskriptif Variabel Penelitian

\begin{tabular}{lccccc}
\hline & N & Minimum & Maximum & Mean & Std. Deviation \\
\hline Sosialisasi Perpajakan & 100 & 8 & 19 & 14.39 & 2.719 \\
Kualitas Pelayanan Fiskus & 100 & 9 & 20 & 15.17 & 2.478 \\
Sanksi Perpajakan & 100 & 8 & 19 & 15.20 & 3.025 \\
Kepatuhan Wajib Pajak & 100 & 8 & 19 & 13.69 & 2.838 \\
Valid N (listwise) & 100 & & & & \\
\hline
\end{tabular}

Sumber: Hasil uji statistik menggunakan Aplikasi SPSS 21.0

Tabel 1, variabel Sosialisasi Perpajakan, responden sangat setuju dengan sosialisasi perpajakan yang dilakukan oleh KPP Pratama Manado. Untuk variabel Kualitas Pelayanan Fiskus, responden memiliki persepsi yang relatif baik atau positif terhadap kualitas pelayanan fiskus yang diberikan oleh Kantor Pelayanan Pajak Manado. Untuk variabel Sanksi Perpajakan, responden setuju terhadap sanksi pajak yang dikenakan kepada wajib pajak yang melalaikan kepatuhan perpajakannya. Sedangkan untuk variabel Kepatuhan Wajib Pajak menunjukkan bahwa responden merupakan wajib pajak yang patuh.

\section{Uji Instrumen Penelitian}

\section{Uji Validitas dan Reliabilitas Data}

Tabel 2. Ringkasan Hasil Perhitungan Validitas dan Realibilitas

\begin{tabular}{lccc}
\hline \multicolumn{1}{c}{ Variabel } & Cronbach Alpha & Indikator & $\begin{array}{c}\text { Corrected Item Total } \\
\text { Correlation }\end{array}$ \\
\hline Sosialisasi (X1) & .743 & $\mathrm{X} 1(1)$ & .712 \\
& & $\mathrm{X} 1(2)$ & .742 \\
& & $\mathrm{X} 1(3)$ & .756 \\
& & $\mathrm{X} 1(4)$ & .592 \\
\hline Kualitas & $\mathrm{X} 2(1)$ & .441 \\
Pelayanan & $\mathrm{X} 2(2)$ & .350 \\
Fiskus (X2) & & $\mathrm{X} 2(3)$ & .514 \\
& & $\mathrm{X} 2(4)$ & .670 \\
\hline Sanksi & .813 & $\mathrm{X} 3(1)$ & .731 \\
Perpajakan (X3) & & $\mathrm{X} 3(2)$ & .690 \\
& & $\mathrm{X} 3(3)$ & .731 \\
& & $\mathrm{X} 3(4)$ & .612 \\
\hline Kepatuhan (Y) & .749 & $\mathrm{Y} 1$ & .550 \\
& & $\mathrm{Y} 2$ & .731 \\
& & $\mathrm{Y} 3$ & .612 \\
\hline
\end{tabular}

Sumber: Hasil uji statistik menggunakan Aplikasi SPSS 21.0 
Tabel 2, hasil perhitungan yang dilakukan mendapatkan hasil yang baik, sehingga dapat di simpulkan bahwa angket dikatakan valid. Sedangkan hasil uji reliabilitas yang dilakukan dengan program statistik SPSS 21 didapat bahwa hasil koefisien Cronbach Alpha lebih besar dari 0,70 untuk empat variabel penelitian yaitu Variabel Sosialisasi Perpajakan (X1) : 0,743 ; Kualitas Pelayanan Fiskus (X2) : 0,717 ; Sanksi perpajakan (X3) : 0,813 ; Kepatuhan wajib pajak (Y) : 0,749 dengan demikian maka dapat disimpulkan bahwa kuesioner untuk ke empat variabel diatas adalah reliable.

\section{Uji Normalitas}

Tabel 3. Hasil Uji Normalitas Data

\begin{tabular}{llr}
\hline & & Unstandardized Residual \\
\hline $\mathrm{N}$ & & 100 \\
\hline Normal Parameters $^{\mathrm{a}, \mathrm{b}}$ & Mean & .0000000 \\
& Std. Deviation & .77438101 \\
Most Extreme Differences & Absolute & .135 \\
& Positive & .135 \\
Kolmogorov-Smirnov Z & Negative & -.131 \\
Asymp. Sig. (2-tailed) & & 1.347 \\
\hline
\end{tabular}

Sumber: Hasil uji statistik menggunakan Aplikasi SPSS 21.0

Tabel 3, terlihat pada kolom Kolmogorov-Smirnov dapat diketahui bahwa nilai signifikansi untuk seluruh variabel lebih besar dari 0,05 yaitu 0,053 maka dapat disimpulkan bahwa data berdistribusi normal.

\section{Uji Multikolinearitas}

\section{Tabel 4. Hasil Uji Multikolinearitas}

\begin{tabular}{|c|c|c|c|c|c|c|c|}
\hline \multirow{3}{*}{ Model } & \multicolumn{4}{|c|}{ Coefficients $^{\mathrm{a}}$} & \multirow{3}{*}{ Sig. } & \multirow{2}{*}{\multicolumn{2}{|c|}{$\begin{array}{c}\text { Collinearity } \\
\text { Statistics }\end{array}$}} \\
\hline & Unstandardizec & Coefficients & $\begin{array}{c}\text { Standardized } \\
\text { Coefficients }\end{array}$ & $\mathbf{t}$ & & & \\
\hline & B & Std. Error & Beta & & & Tolerance & VIF \\
\hline (Constant) & .826 & .517 & & 1.600 & .113 & & \\
\hline $\begin{array}{l}\text { Sosialisasi } \\
\text { Perpajakan } \\
\end{array}$ & 1.351 & .074 & 1.294 & 18.200 & .000 & .153 & 6.521 \\
\hline 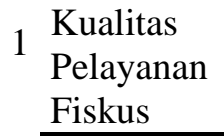 & -.177 & .042 & -.155 & -4.221 & .000 & .578 & 1.730 \\
\hline $\begin{array}{l}\text { Sanksi } \\
\text { Perpajakan }\end{array}$ & -.256 & .061 & -.273 & -4.227 & .000 & .186 & 5.374 \\
\hline
\end{tabular}

a. Dependent Variable: Kepatuhan Wajib Pajak

Sumber: Hasil uji statistik menggunakan Aplikasi SPSS 21.0 
Tabel 4, nilai VIF untuk masing-masing variabel independen memiliki nilai tolerance > 0,10 dan nilai VIF tidak lebih dari 10, sehingga dapat dinyatakan bahwa model regresi linear berganda terbebas dari asumsi multikolinearitas.

\section{Uji Heterokedastisitas}

\section{Gambar 1. Hasil Uji Heteroskedastisitas}

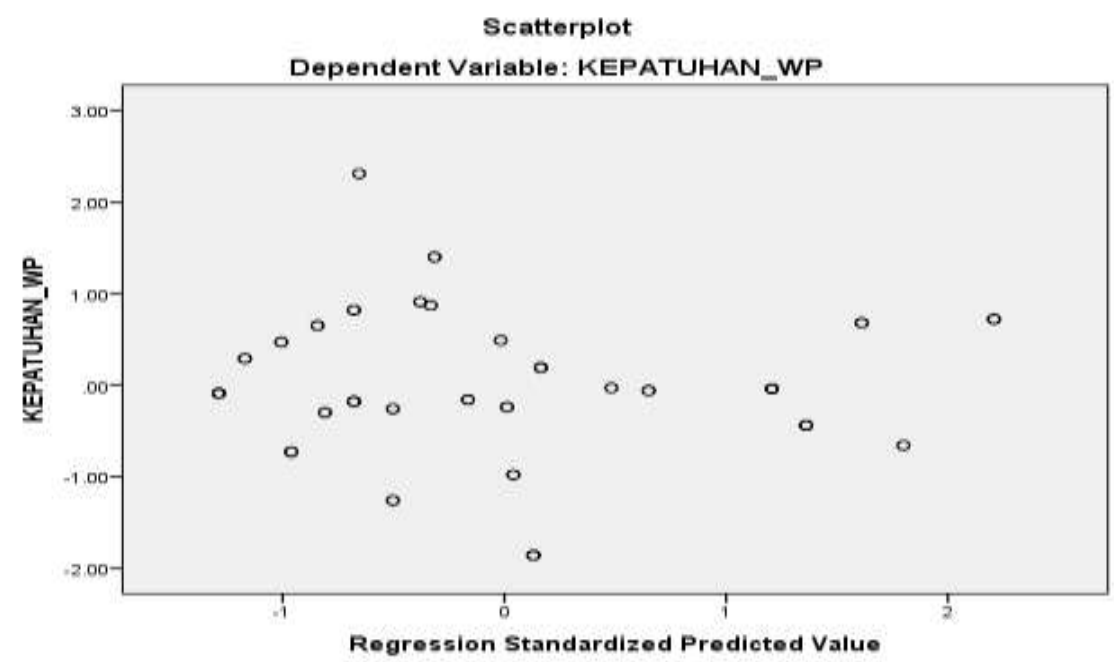

Sumber: Hasil uji statistik menggunakan Aplikasi SPSS 21.0

Gambar 1, penyebaran titik-titik data yaitu titik-titik data menyebar di atas dan di bawah angka 0 dan tidak mengumpul hanya diatas atau di bawah saja. Hal ini dapat disimpulkan bahwa tidak terjadi heteroskedastisitas. Karena tidak terjadi heterokedastisitas maka model regresi ganda layak digunakan dalam penelitian ini.

\section{Uji Hipotesis}

Uji Parsial (Uji t)

Tabel 5. Hasil Uji Parsial (Uji t)

\begin{tabular}{|c|c|c|c|c|c|c|}
\hline \multirow[t]{2}{*}{ Mode } & & \multicolumn{2}{|c|}{$\begin{array}{l}\text { Unstandardized } \\
\text { Coefficients }\end{array}$} & \multirow{2}{*}{$\begin{array}{c}\begin{array}{c}\text { Standardized } \\
\text { Coefficients }\end{array} \\
\text { Beta }\end{array}$} & \multirow[t]{2}{*}{$\mathbf{T}$} & \multirow[t]{2}{*}{ Sig. } \\
\hline & & B & $\begin{array}{l}\text { Std. } \\
\text { Error }\end{array}$ & & & \\
\hline \multirow{5}{*}{1} & (Constant) & .826 & .517 & & 1.600 & .113 \\
\hline & Sosialisasi & 1.351 & .074 & 1.294 & 18.200 & .000 \\
\hline & Perpajakan & & & & & \\
\hline & $\begin{array}{l}\text { Kualitas Pelayanan } \\
\text { Fiskus }\end{array}$ & -.177 & .042 & -.155 & -4.221 & .000 \\
\hline & Sanksi Perpajakan & -.256 & .061 & -.273 & -4.227 & .000 \\
\hline
\end{tabular}

a. Dependent Variable: Kepatuhan Wajib Pajak

Sumber: Hasil uji statistik menggunakan Aplikasi SPSS 21.0 
Tabel 5 menunjukkan bahwa:

1. Variabel Sosialisasi Perpajakan

Diperoleh $t_{\text {hitung }}-t_{\text {tabel }}(18,200>1,985)$ dan tingkat signifikansi $<0,05(0,000<0,05)$, maka keputusan yang diambil adalah Ho1 ditolak dan Ha1 diterima, artinya terdapat pengaruh antara sosialisasi perpajakan $\left(\mathrm{X}_{1}\right)$ terhadap kepatuhan wajib pajak orang pribadi (Y).

2. Variabel Kualitas Pelayanan Fiskus

Oleh karena $t_{\text {hitung }}<$ dari $t_{\text {tabel }}(-4,221<1,985)$ dan tingkat signifikansi $<0,05(0,000<0,05)$, maka keputusan yang diambil adalah $\mathrm{Ho}_{2}$ terima dan $\mathrm{Ha} 2$ ditolak, artinya tidak terdapat pengaruh antara kualitas pelayanan fiskus $\left(\mathrm{X}_{2}\right)$ terhadap kepatuhan wajib pajak orang pribadi (Y).

3. Variabel Sanksi Perpajakan

Oleh karena thitung < dari tabel $(-4,227<1,985)$ dan tingkat signifikansi $<0,05(0,000<$ 0,05), maka keputusan yang diambil adalah Ho3 diterima dan Ha3 ditolak, artinya tidak terdapat pengaruh antara sanksi perpajakan (X3) terhadap kepatuhan wajib pajak orang pribadi (Y).

\section{Uji Simultan (Uji F)}

Tabel 6. Hasil Uji Simultan (Uji F)

\begin{tabular}{rlrrrrr}
\hline Model & & Sum of Squares & df & Mean Square & \multicolumn{1}{c}{ F } & \multicolumn{1}{c}{ Sig. } \\
\hline \multirow{2}{*}{1} & Regression & 738.023 & 3 & 246.008 & 397.810 & $.000^{b}$ \\
& Residual & 59.367 & 96 & .618 & & \\
& Total & 797.390 & 99 & & & \\
\hline
\end{tabular}

a. Dependent Variable: Kepatuhan Wajib Pajak

b. Predictors: (Constant), Sanksi Perpajakan, Kualitas Pelayanan Fiskus, Sosialisasi Perpajakan

Sumber: Hasil uji statistik menggunakan Aplikasi SPSS 21.0

Tabel 6, karena Fhitung $>$ Ftabel $(397,810>2,70)$ dan tingkat signifikansi $<0,05$ $(0,000<0,05)$, maka keputusan yang diambil adalah Ho ditolak dan Ha diterima. Dengan kata lain bahwa persamaan regresi yang terbentuk dari variabel sosialisasi perpajakan (X1), kualitas pelayanan fiskus (X2), dan sanksi perpajakan (X3) sebagai variabel independen secara bersamasama berpengaruh terhadap kepatuhan wajib pajak orang pribadi (Y) sebagai variabel dependen.

\section{Analisis Regresi Linear Berganda}

Persamaan regresi untuk sosialisasi perpajakan, kualitas pelayanan fiskus, dan sanksi perpajakan terhadap kepatuhan wajib pajak orang pribadi pada tabel 5 adalah sebagai berikut: $\mathrm{Y}=\mathbf{0 , 8 2 6}+\mathbf{1 , 3 5 1 X _ { 1 } - 0 , 1 7 7 X _ { 2 } - 0 , 2 5 6 X _ { 3 }}$

Dimana:

$\mathrm{Y}=$ Kepatuhan Wajib Pajak

$\mathrm{X}_{1}=$ Sosialisasi Perpajakan

$\mathrm{X}_{2}=$ Kualitas Pelayanan Fiskus

$\mathrm{X} 3$ =Sanksi Perpajakan 
Pada model regresi ini, nilai konstanta sebesar 0,826 yang berarti jika variabel independen dalam model diasumsikan sama dengan nol, maka variabel independen diluar model tetap akan meningkatkan kepatuhan wajib pajak sebesar 0,826 satuan.

Variabel sosialisasi perpajakan $\left(\mathrm{X}_{1}\right)$ berpengaruh terhadap kepatuhan wajib pajak (Y) dengan nilai besaran koefisien regresi $\beta 1$ sebesar 1,351 hal ini menunjukkan bahwa setiap satuan variabel sosialisasi perpajakan akan berpengaruh terhadap kepatuhan wajib pajak sebesar 1,351 apabila variabel lainnya tetap. Dengan kata lain, setiap peningkatan sosialisasi perpajakan akan berpengaruh pada peningkatan kepatuhan wajib pajak.

Variabel kualitas pelayanan fiskus (X2) tidak berpengaruh terhadap kepatuhan wajib pajak (Y) dengan nilai besaran koefisien regresi $\beta 2$ sebesar -0,177 hal ini menunjukkan bahwa setiap satuan variabel pelayanan fiskus tidak akan berpengaruh terhadap kepatuhan wajib pajak sebesar -0,177 apabila variabel lainnya tetap. Dengan kata lain setiap peningkatan kualitas pelayanan fiskus tidak akan berpengaruh terhadap kepatuhan wajib pajak.

Variabel sanksi perpajakan (X3) tidak berpengaruh terhadap kepatuhan wajib pajak (Y) dengan nilai besaran koefisien regresi $\beta 3$ sebesar -0,256 hal ini menunjukkan bahwa setiap satuan variabel sanksi pajak tidak akan berpengaruh terhadap kepatuhan wajib pajak sebesar 0,256 apabila variabel lainnya tetap. Dengan kata lain, setiap peningkatan sanksi perpajakan tidak akan berpengaruh pada peningkatan kepatuhan wajib pajak.

\section{Pembahasan}

Hasil pengujian hipotesis secara parsial dapat disimpulkan bahwa terdapat pengaruh antara sosialisasi perpajakan terhadap kepatuhan wajib pajak orang pribadi. Hal ini sejalan dengan hasil penelitian sebelumnya yaitu penelitian yang dilakukan oleh Soebagyo (2005) tentang Pengaruh Sosialisasi Perpajakan oleh Ditjen Pajak Terhadap Kepatuhan Wajib Pajak pada KPP Jakarta Kemayoran menunjukkan bahwa sosialisasi perpajakan mampu mempengaruhi kepatuhan Wajib Pajak badan dengan nilai 10,4\% dan Wajib Pajak orang pribadi 8,3\%. Kemudian penelitian yang dilakukan oleh Setianto (2010) tentang Pengaruh Sosialisasi Perpajakan dan Pelaksanaan Self Assesment System terhadap Tingkat Kesadaran dan Kepatuhan Wajib Pajak pada Kantor Pelayanan Pajak Jakarta Cilandak menunjukkan sosialisasi perpajakan dan self assesment system berpengaruh signifikan terhadap tingkat kesadaran dan kepatuhan Wajib Pajak sebesar 51,3\% atau dengan kata lain 48,7\% dipengaruhi oleh faktor lain. Selanjutnya penelitian yang dilakukan oleh Restiani dalam Puspitasari (2013) menunjukkan bahwa kualitas pelayanan pajak dan sosialisasi perpajakan memiliki pengaruh yang signifikan terhadap kepatuhan formal Wajib Pajak orang pribadi secara parsial dan simultan pada Kantor Pelayanan Pajak Pratama di wilayah Kota Cianjur.

Hasil pengujian hipotesis secara parsial dapat disimpulkan bahwa tidak terdapat pengaruh antara kualitas pelayanan fiskus terhadap kepatuhan wajib pajak orang pribadi. Hasil penelitian ini tidak sejalan dengan hasil penelitian Jatmiko (2006), Arum (2012) dan Saragih (2013) yang menemukan bahwa kualitas pelayanan fiskus berpengaruh signifikan terhadap kepatuhan wajib pajak. Hal ini dapat terjadi karena belum maksimalnya kualitas pelayanan dari fiskus terhadap wajib pajak. (Winerungan, 2013) menyatakan salah satu langkah penting yang harus dilakukan pemerintah sebagai wujud nyata kepedulian pada pentingnya kualitas pelayanan adalah memberikan pelayanan prima kepada wajib pajak dalam mengoptimalkan penerimaan negara. 
Hasil pengujian hipotesis secara parsial dapat disimpulkan bahwa tidak terdapat pengaruh antara sanksi perpajakan terhadap kepatuhan wajib pajak orang pribadi. Hasil penelitian ini sejalan dengan hasil penelitian Winerungan (2013) dan Najib (2013) yang menemukan sanksi perpajakan tidak memiliki hubungan yang signifikan dengan kepatuhan wajib pajak. Hal ini dapat disebabkan karena masih kurangnya kesadaran masyarakat di kota Manado tersebut terhadap pentingnya pajak untuk kelancaran pembangunan kota, yang selanjutnya mempengaruhi kepatuhan pajak orang pribadi.

Hasil hipotesis secara simultan, dapat disimpulkan bahwa terdapat pengaruh antara sosialisasi perpajakan, kualitas pelayanan fiskus dan sanksi perpajakan terhadap kepatuhan wajib pajak orang pribadi. Hasil penelitian ini sejalan dengan hasil penelitian Jatmiko (2006), Arum (2012), Puspitasari (2013) dan Marjan (2014) yang menemukan bahwa terdapat hubungan yang signifikan antara variabel independen (sosialisasi perpajakan, kualitas pelayan pajak dan sanksi perpajakan) terhadap variabel dependen (kepatuhan wajib pajak). Hal ini dapat terjadi karena ketiga variabel independen merupakan faktor yang saling berhubungan dan saling mempengaruhi, sehingga apabila di jalankan secara simultan dapat mewujudkan tingkat kepatuhan wajib pajak yang maksimal.

\section{Kesimpulan}

\section{PENUTUP}

Kesimpulan dari penelitian ini adalah:

1. Terdapat pengaruh sosialisasi perpajakan terhadap kepatuhan wajib pajak orang pribadi.

2. Tidak terdapat pengaruh kualitas pelayanan terhadap kepatuhan wajib pajak orang pribadi.

3. Tidak terdapat pengaruh sanksi perpajakan terhadap kepatuhan wajib pajak orang pribadi.

4. Persamaan regresi yang terbentuk dari variabel sosialisasi perpajakan, kualitas pelayanan fiskus, dan sanksi perpajakan sebagai variabel independen secara bersama-sama berpengaruh terhadap kepatuhan wajib pajak orang pribadi sebagai variabel dependen.

\section{Saran}

Saran sebagai bahan masukan untuk KPP Pratama Manado sebagai berikut:

1. Untuk Kantor Pelayanan Pajak Pratama Manado, petugas pajak sebaiknya harus lebih giat dalam menerapkan upaya-upaya untuk meningkatkan kepatuhan wajib pajak seperti melakukan penyuluhan dan sosialisasi pajak kepada masyarakat, bertindak profesional dan memiliki mental yang siap melayani wajib pajak dengan sebaik-baiknya serta memberikan fasilitas yang memadai kepada wajib pajak agar wajib pajak merasa puas dan melaksanakan kewajiban perpajakannya secara sukarela. Sanksi pajak juga harus disosialisasikan dengan baik kepada wajib pajak agar wajib pajak dapat memahami hal-hal yang berkaitan dengan pelaksanaan sanksi pajak dan penyebab-penyebab dikenakannya sanksi pajak tersebut serta perlu ditingkatkan pengenaan sanksi pajak terhadap wajib pajak yang tidak memenuhi kewajiban perpajakannya agar wajib pajak jera dan dapat meningkatkan kepatuhan perpajakannya.

2. Untuk peneliti selanjutnya, diharapkan dapat menggali variabel-variabel independen lainnya yang bertujuan untuk mengetahui variabel-variabel lain yang dapat mempengaruhi kepatuhan wajib pajak orang pribadi. Peneliti juga diharapkan dapat menambah jumlah sampel penelitian. 


\section{DAFTAR PUSTAKA}

Arum H. P., 2012. Pengaruh Kesadaran Wajib Pajak, Pelayanan Fiskus dan Sanksi Pajak Terhadap Kepatuhan Wajib Pajak Orang Pribadi Yang Melakukan Kegiatan Usaha Dan Pekerjaan Bebas (Studi Di Wilayah KPP Pratama Cilacap). Fakultas Ekonomika dan Bisnis Universitas Diponegoro. Skripsi Undip. Semarang. http://eprints.undip.ac.id/35890/1/SKRIPSI_ARUM.pdf. Diakses tanggal 04 Oktober 2014. Hal. 1-71.

Fikriningrum W. K., 2012. Analisis Faktor-Faktor Yang Mempengaruhi Wajib Pajak Orang Pribadi Dalam Memenuhi Kewajiban Membayar Pajak (Studi Kasus Pada Kantor Pelayanan Pajak Pratama Semarang Candisari). Fakultas Ekonomika dan Bisnis Universitas Diponegoro. Skripsi Undip. Semarang. http://eprints.undip.ac.id/36149/1/FIKRININGRUM.pdf. Diakses tanggal 06 Juni 2014. Hal. 1-42.

Herryanto M., 2009. Pengaruh Kesadaran Wajjib Pajak, Kegiatan Sosialisasi Perpajakan dan Pemeriksaan Pajak Terhadap Penerimaan Pajak Penghasilan Di KPP Pratama Surabaya Sawahan. Fakultas Ekonomi Universitas Kristen Petra. Surabaya. Jurnal UKP Tax \& $\begin{array}{lllll}\text { Accounting } & \text { Review, } & \text { Vol. } & 1 & \text { No. }\end{array}$ http://studentjournal.petra.ac.id/index.php/akuntansi-pajak/article/viewFile/450/389.

Diakses tanggal 06 Juni 2014. Hal. 124-135.

Jatmiko A. N. 2006. Pengaruh Sikap Wajib Pajak Pada Pelaksanaan Sanksi Denda, Pelayanan Fiskus dan Kesadaran Perpajakan Terhadap Kepatuhan Wajib Pajak Orang Pribadi Di Kota Semarang. Program Pascasarjana Universitas Diponegoro. Tesis Undip, Semarang. http://eprints.undip.ac.id/6812/1/Agus_Nugroho_Jatmiko.pdf. Diakses tanggal 06 Juni 2014. Hal. 1-69.

Marjan, R. M., 2014. Pengaruh Kesadaran Wajib Pajak, Pelayanan Fiskus, Dan Sanksi Pajak Terhadap Tingkat Kepatuhan Formal Wajib Pajak (Studi di Kantor Pelayanan Pajak Pratama Makassar Selatan). Fakultas Ekonomi Dan Bisnis Universitas Hasanuddin, Makassar. Skripsi Unhas. http://repository.unhas.ac.id/bitstream/handle/123456789/10227/SKRIPSI\%20RESTU \%20MUTMAINNAH\%20MARJAN\%20PDF.pdf?sequence=1. Diakses tanggal 10 Oktober 2014. Hal. 1-78.

Najib F. D., 2013. Analisis Faktor-Faktor Yang Mempengaruhi Kepatuhan Wajib Pajak Orang Pribadi Dalam Membayar Pajak Penghasilan (Studi Pada Wajib Pajak Orang Pribadi KPP Pratama Malang Utara). Program Studi Akuntansi Universitas Brawijaya, Malang. Jurnal Unbraw. http://jimfeb.ub.ac.id/index.php/jimfeb/article/download/601/544. Diakses tanggal 10 Oktober 2014. Hal. 1-12.

Puspitasari N. A., 2013. Analisis Sosialisasi Peraturan Perpajakan Dalam Upaya Peningkatan Kepatuhan Wajib Pajak (Studi Kasus Pada Kantor Wilayah Direktorat Jenderal Pajak Jawa Timur I Surabaya). Fakultas Ekonomi Dan Bisnis Universitas Airlangga, Surabaya. Skripsi

Unair. https://www.academia.edu/4040373/JURNAL_ANALISIS_SOSIALISASI_PERATURA N_PERPAJAKAN_DALAM_UPAYA_PENINGKATAN_KEPATUHAN_WAJIB_PAJ AK. Diakses tanggal 10 Oktober 2014. Hal. 1-28.

Salahuddin, 2005. Penagihan Pajak Secara Paksa Terhadap Wajib Pajak Yang Tidak Melaksanakan Kewajibannya Pada Kantor Pelayanan Pajak Medan Barat. Fakultas 
Hukum Universitas Sumatera Utara, Medan. Skripsi USU.http://www.researchgate.net/publication/42354059_Penagihan_Pajak_Secara_Paksa _Terhadap_Wajib_Pajak_Yang_Tidak_Melaksanakan_Kewajibannya_Pada_Kantor_Pela yanan_Pajak_Medan_Barat. Diakses tanggal 06 Juni 2014. Hal. 1-146.

Saragih S. F., 2013. Analisis Pengaruh Sosialisasi Perpajakan, Kualitas Pelayanan Fiskus Dan Sanksi Perpajakan Terhadap Kepatuhan Wajib Pajak Orang Pribadi Di Kantor Pelayanan Pajak (KPP) Pratama Medan Timur. Fakultas Ekonomi Universitas Sumatera Utara, Medan. Skripsi USU. http://repository.usu.ac.id/handle/123456789/39496. Diakses tanggal 06 Juni 2014.Hal. 1-65.

Setianto E., 2010. Pengaruh Sosialisasi Perpajakan dan Pelaksanaan Self Assesment System Terhadap Tingkat Kesadaran dan Kepatuhan Wajib Pajak Pada Kantor Pelayanan Pajak Jakarta Cilandak. Fakultas Ekonomi Universitas Pembangunan Nasional Veteran Jakarta. Jakarta. Skripsi http://www.library.upnvj.ac.id/pdf/s1manajemen09/204112026/abstrak.pdf. Diakses tanggal 10 Oktober 2014. Hal 1-65.

Soebagyo FX. I. S., 2005. Pengaruh Sosialisasi Oleh Ditjen Pajak Terhadap Kepatuhan Wajib Pajak Pada KPP Jakarta Kemayoran. Fakultas Ekonomi Universitas Indonesia., Depok. Skripsi UI. http://lib.ui.ac.id/file?file=pdf/metadata-108279.pdf. Diakses tanggal 10 Oktober 2014. Hal. 1-75.

Sugiyono, 2013. Metode Penelitian Bisnis. Cetakan Ketujuhbelas. Alfabeta. Bandung.

Tryana, 2013. Kesadaran Perpajakan, Sanksi Pajak, Sikap Fiskus Terhadap Kepatuhan WPOP Di Kabupaten Minahasa Selatan. Fakultas Ekonomi Dan Bisnis Universitas Sam Ratulangi, Manado. Jurnal EMBA Vol. 1 No. 3 September 2013, Hal. 999-1008. Diakses tanggal 06 Juni 2014.

Winerungan O. L., 2013. Sosialisasi Perpajakan, Pelayanan Fiskus dan Sanksi Perpajakan Terhadap Kepatuhan WPOP di KPP Manado dan KPP Bitung. Fakultas Ekonomi Dan Bisnis Universitas Sam Ratulangi, Manado. Jurnal EMBA ISSN 2303-1174. http://ejournal.unsrat.ac.id/index.php/emba/article/download/2301/1855. Diakses tanggal 10 Oktober 2014. Hal. 960-970.

Undang-Undang Nomor 28 Tahun 2007 tentang Perubahan Ketiga atas Undang-Undang Nomor 6 Tahun 1983 tentang Ketentuan Umum dan Tata Cara Perpajakan 